\title{
Business model for Indian Tier II and Tier III cities - A study for fashion \& lifestyle products
}

\author{
Tanmay Kandekar \\ Assistant Professor \\ Department of Fashion Management Studies \\ National Institute of Fashion Technology, Mumbai
}

\begin{abstract}
As per rating of Global Retail Development Index (GRDI), 2017 India ranked 1st among 30 developing countries, surpassing China, in terms of retail sector development. In order to leverage this market scope all the key international brands are foraying into Indian market to lure the Indian customers with their market offerings. The grand entry of Amazon is the latest proof of the huge potential in Indian retail space. The Indian home grown brands are also not much behind in capitalizing on this growth trajectory. However this competitive landscape has begun saturating the Indian metros and tier I cities. As such the retail brands are in dire need to expand into tier II and tier III cities. These cities provide a less cluttered market space with high awareness and purchasing power, which can be en-cashed by the fashion brands with carefully crafted marketing mix strategies. However the prerequisite to this strategic initiative is to understand the psychographics and aspiration levels of this target segment.

The objective of this research paper is to identify the aspirations and purchase behavior of tier II and tier III Indian consumers and suggest various effective strategies to promote fashion products in these cities.

The research methodology includes the detailed survey of customers from Tier II and tier III cities. A survey of 500 customers over a period of 3 months was conducted to find out the perception and awareness of fashion products among the customers along with the issues they face while purchasing the product.

This paper concludes with formulation of various strategies on the basis of 4P's of marketing that can be implemented by the companies, which want to capture the highly growing market of more than 3000 towns. These strategies are formulated considering the consumer behavior of these cities, their aspirations that are backed by the purchasing power. These strategies may help marketers to capture the demand for the fashion brands from these cities.
\end{abstract}

\section{Introduction:}

India is considered as a land of opportunities where it is a great attraction for the international companies for investment and expansion. India has also opened its economy by allowing 51\% FDI in multi brand retail. The organized retail is only about $9 \%$ in India, and the most of it are concentrated tier I. There is huge potential for the rest of the urban area to match with the metro in terms of penetration on fashion brands. Out of its 1.25 billion-population and 356 million youth having age of 10-24 years, it's a market, which is not tapped by the brands yet.

As per population censes 2011, India has 8 tier I cities, 47 tier II cities and more than 300 tier III cities. There are around 100 towns, which are on the way to become tier III cities. There is huge potential in tier II and tier III cities as the retail growth rate is around $50 \%$ as compared to $20 \%$ in metros and other tier I cities.

But the customer behavior of these areas is way different from the metros. The customers are more prices sensitive, less experimental in online purchase, and not well versed with online transactions. 
In such situation, marketer may face challenges in creating marketing and product mix. A specific strategy should be formulized after considering the attributes of the target population.

A survey is conducted with 500 respondents in tier II and tier III cities, to find out the perception and awareness of fashion products among the customers along with their purchasing behavior and the issues they face while purchasing the product. A detailed analysis of this survey revealed the traits of the customers of these cities. These characteristics are used to formulate various strategies for the brands to foray into these markets.

\section{Objectives:}

- To analyze the recent trends in retailing in tier II and tier III cities

- To analyze the consumer behavior of Tier II and tier III cities

- To create a matrix of preferences as per the various customer categories to strategies marketing efforts

\section{Literature survey:}

For Business expansion, in last 10 years major emphasis of brands were on the metro like Mumbai, Chennai, Bangalore, Delhi and mini- metro for examples, Pune, Kolkata, Gurgaon near Delhi, Gurgaon and suburbs near Mumbai. These brands extracted huge demand by tapping the right cords of cash rich customers in these regions. Even though these markets are not completely saturated, but the growth rate has surely dipped. So its obvious for the brands to look for other emerging areas like tier II and tier III cities, which has huge potential. These areas have it's own set of challenges. The most critical is the awareness of products and efficient connectivity. The most important channel of communication is through smartphones.

Data as per December 2017 shows that even though more than $94 \%$ urban households own mobile phones for personal or official purpose, Internet connectivity at reasonable rates is still at $64.8 \%$ (295 million out of 455 million people). Still most of people depend on the computer based Internet services café. Once the Internet reaches to more people, there will be rise in the ecommerce demand. Rural India has much lesser penetration that's is $20.26 \%$ (186 million out of 918 million people).

According to report published in Newsnation (2014), e- commerce is still in nascent stage and shows huge potential in India. It is estimated that, by 2023 , it will be $7 \%$ of India's retail market amounting to USD 60 Billion. Currently the majority of customers doing online transaction are from tier I cities and it is expected to grow at a rate of $40 \%$. The size of the industry was USD 1.5 billion in 2012 and grew to USD 17.8 billion in 2017 growing at the rate of 23\%. In 2015 India recorded 
50 million online shoppers and it is expected to touch 175 million by 2020. Customers from tier II are not far behind. Internet is spreading its wings in tier II and tier III cities across India, which are untapped by the brands. So these are the areas to look out for. As per Shilpa Elizabeth (2015) in her article on amazon points out that there is huge increase in demand from tier II cities. These 12 emerging tier-II cities, which show high growth in retail market potential and maturity are Chandigarh, Ludhiana, Vadodara, Raipur, Amritsar, Surat, Lucknow, Nagpur, Indore, Coimbatore, Kanpur and Jaipur. The tier III cities, which are catching fast with tier II, are Kolhapur, Hosur, Jaisalmer, Rajkot, Ooty, Aurangabad, Coonoor, Valsad, Nashik, Belgaum, Mangalore, and Vapi.

The use of smartphone and availability of Internet, Television, and the higher income levels leads to increased awareness among people about various brands. These people want to imitate the consumption habits of tier I customers. There is major boost of sales from tier II cities in e-commerce as the desired products are not available in their city limits. There is huge potential for the brands to sell products to Tier II and Tier III cities. E-bay a leading ecommerce company has experiencing huge growth in their sales coming from these cities. As per Mr. Latif Nathani Managing Director of eBay, "India is experiencing tremendous growth and the potential it has is very promising. We are seeing almost 50 per cent of the business coming from tier II and III cities". But these cities are not easy to decode. The structure of these towns is different in term of the geography, demography, price sensitiveness, purchase quantity, ticket size etc. That's why a strategy specific to these towns is the need of an hour. Even though these cities show very promising future for marketers, but are these cities ready to accept the change these brands are expecting is the ultimate question and the companies need to understand all the equations to get a foot hold in these cities.

As per the report published by Stake Business Solution (2015), understanding the consumer behavior is the most important. The customers purchase the product less out of necessity but more because it will be a status symbol for them. They feel to have a luxury brand in their home or wardrobe, but customers are also price sensitive. So positioning of product will be critical to enter into the minds of consumers. It is important for the brands to understand that positioning is not something you do, but rather, is the result of your customer's perception of what you do. Positioning is not something we can create in a vacuum — the act of positioning is a co-authored experience with the customers. Companies need to understand the market dynamics better and faster.

According to a study conducted by NASSCOM in 2010, increase in the education levels in youth of tier II and III cities leads it become talent hubs, from where the IT and BPO sector is drawing its manpower resources. Government of India implemented its policy for the financial upliftment of tier II cities by setting up the BPO industry, giving employment to the educated youth. This in turn improved the disposable income of the people motivating them for taking part in the growing retail industry. There are cities like Pune, Ahmedabad, Gurgaon showing lot of retail attraction and has 
been upgraded to tier I cities. There are many examples where cities are improving with their infrastructure and consumer awareness. These tier III cities like, Nashik, Trichy, Siliguri, Amaravati, Mangalore, Hubli etc. are growing at an unprecedented rate.

The McKinsey Global Institute (MGI) paints the following scenario for 2030:

- Urbanization will spread across India, impacting almost every state

- For the first time in the country's history, there will be five large states - Tamil Nadu, Maharashtra, Karnataka, Gujarat and Punjab - that will have more of their population living in cities rather than villages

- India will have 68 cities with a population of over one million by 2030

India will have 68 cities with population of more than 1 million by 2030 , up from $\mathbf{4 2 \text { today }}$

Population by tier Million

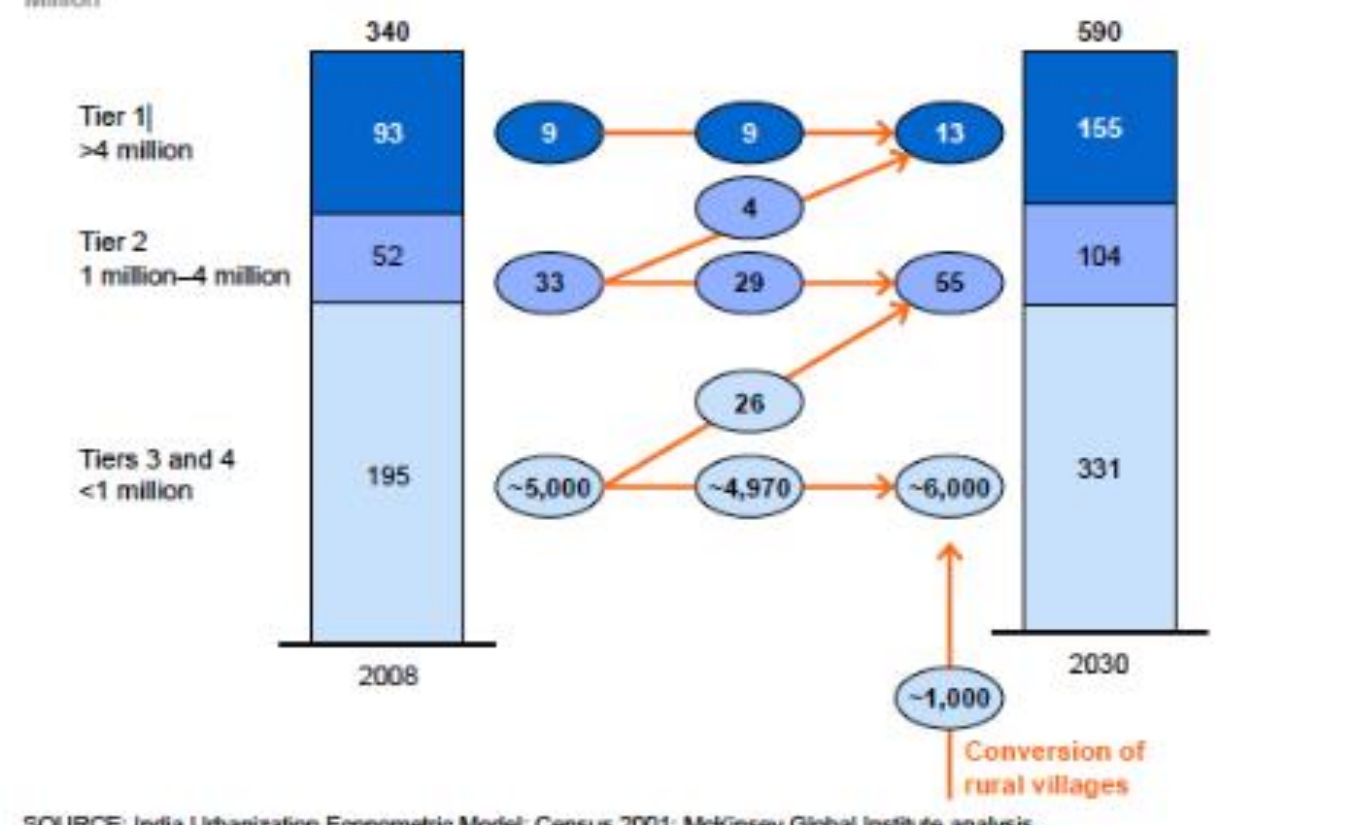

Fig 1: Shift in Tier levels from 2008 to 2030 in India 


\subsection{Emerging cities:}

As per the census 2011, the number of tier II and tier III cities of India are listed below.

Table I: Classification of cities as per the population

\begin{tabular}{|c|c|c|}
\hline $\begin{array}{c}\text { Sr. } \\
\text { no }\end{array}$ & Population & Number of cities \\
\hline 1 & $\begin{array}{c}\text { More than 10 million } \\
\text { (including conglomerate) }\end{array}$ & 3 (Mumbai, Delhi, Kolkata) \\
\hline 2 & Between 5 to 10 million & $5 \quad$ (Bangalore, Chennai, Ahmedabad, \\
& Hyderabad, Pune) \\
\hline 3 & Between 1 to 5 million & 47 \\
\hline 4 & Between 1 million to 0.1 & 443 \\
\hline
\end{tabular}

Source: http://www.census2011.co.in/city.php

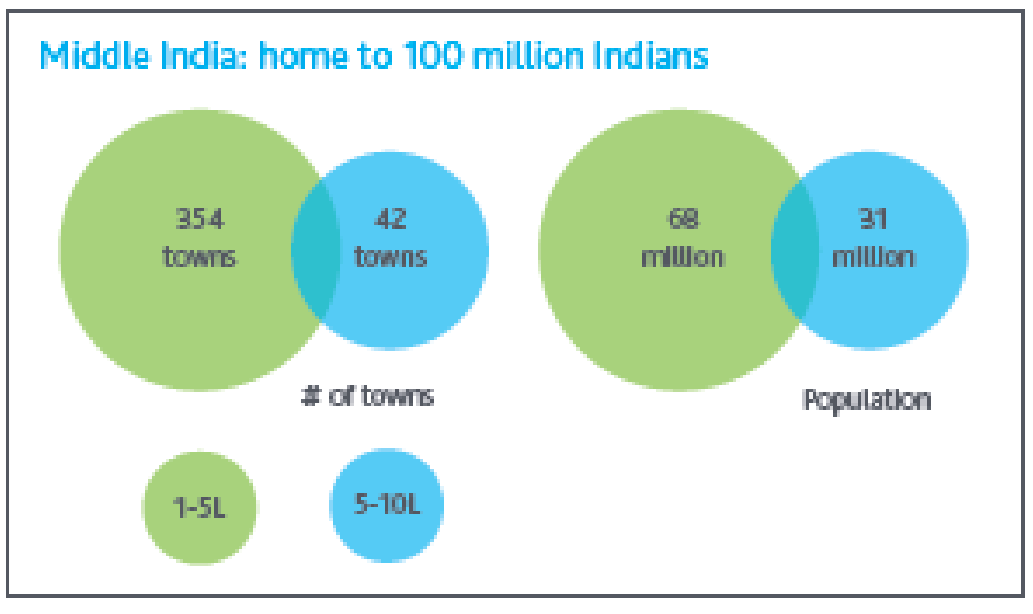

Source: Nieben

Fig 2: Comparison of proportion of town Vs population in India as per 2012

\subsection{The educated women power:}

As the education level of girls is increasing, they inclined more towards online shopping and luxury products. They are the main driving force towards emergence and expansion of fashion productsAs per AT Karney \& Google study, the share of women online consumes will increase to $40 \%$ from 20\% (as per 2015). This information can be critical for the brands to decide their marketing and sales strategy. It is evident from the advertisement that run on television that brands keep the behavior of women in mind to develop the promotional strategy. 
8th International Conference on Modern Research in

Management, Economics and Accounting

October 19 - 21, 2018 / Munich - Germany

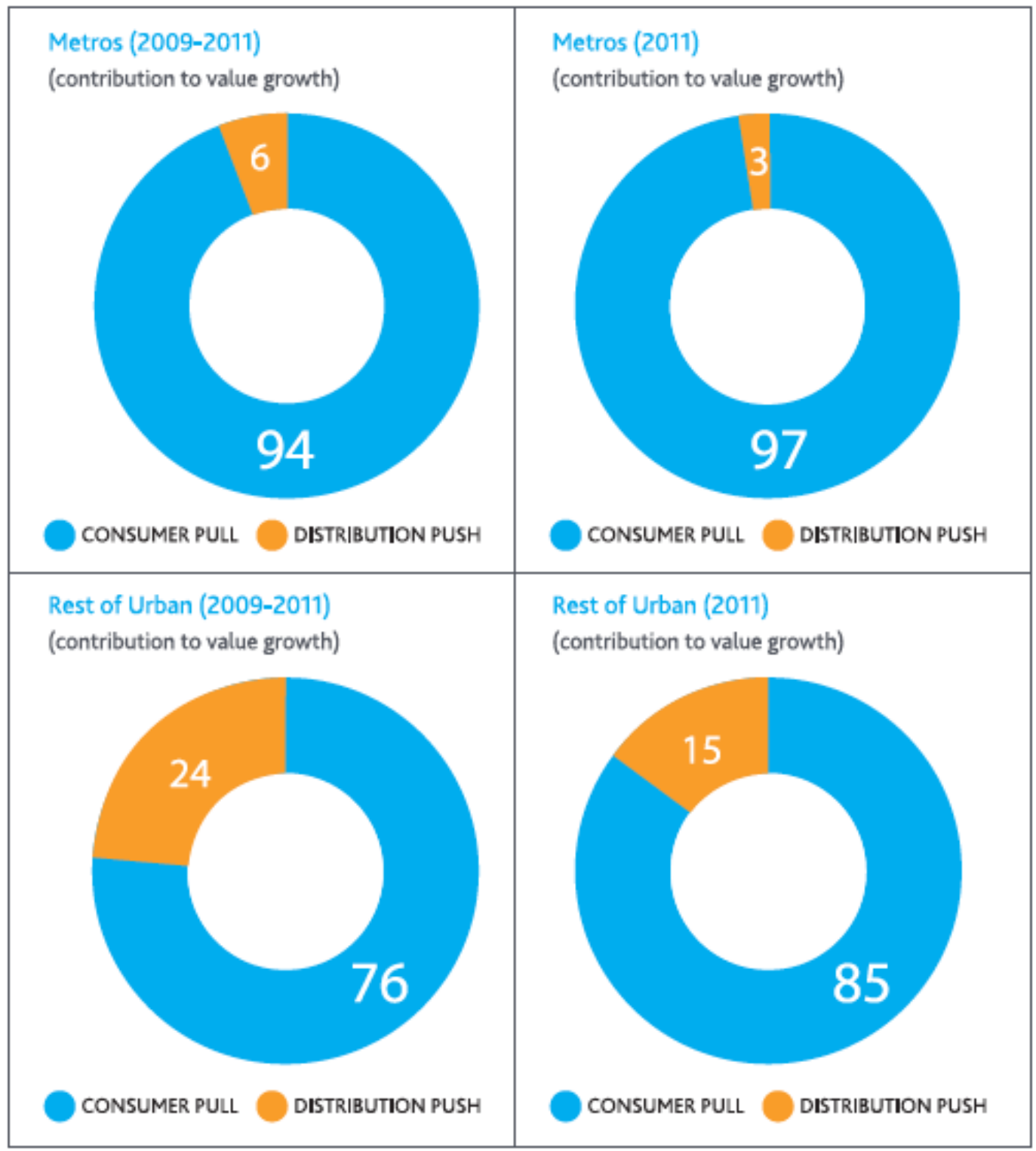

source: Nielsen \& CII report

Fig 3: Comparison of Metros and rest of urban areas with respect to consumer pull vs distribution push

As of the 2011 census, there are 8 tier 1 cities in India - Ahmedabad, Bangalore, Chennai, Delhi, Hyderabad, Kolkata, Mumbai and Pune having population more than 5 million and 47 tier II cities having population more than 1 million and less than 5 million. As compared to these, there are as many as 3,133 towns and more than 1,233 rural hubs. More than $90 \%$ of Indian population lives in tier II and below, which cannot be ignored by the fashion brands. 
FMGC industry has used this opportunity to large extent. There are various companies who started low cost products, which are value for money for non-metro customers. They entered into the homes of millions by promoting heavily on the televisions and forcing the customers to visit near grocery store to find out the product. It is observed that the demand in this category is mostly customer driven. People generally queued up at the store to demand new product in cosmetics, detergents, soaps and chocolates as soon as it is displayed on TV. According to Pankaj Renjhen, Managing Director, Retail Services, Jones Lang LaSalle India (2011) there are cities, which are having specific characteristics and had potential to grow are as follows:

\begin{tabular}{|c|c|c|c|}
\hline $\begin{array}{l}\text { Sr } \\
\text { no }\end{array}$ & $\begin{array}{l}\text { Name of } \\
\text { town }\end{array}$ & Classification & Characteristics \\
\hline 1 & Chandigarh & II & $\begin{array}{l}1.1 \text { million populations, Higher car density High } \\
\text { per capita expenditure with income more than } 0.5 \\
\text { million. High retail penetration. }\end{array}$ \\
\hline 2 & Surat & II & $\begin{array}{l}4.5 \text { million Population, fast growing industrial } \\
\text { sector is giving a boost to retail space development, } \\
\text { population is very young because of migration, the } \\
\text { home to diamond industry of India, }\end{array}$ \\
\hline 3 & Nagpur & II & $\begin{array}{l}2.5 \text { million population, high literacy rate as per } \\
2011 \text { census, Ninth most populous city in India, } \\
\text { National Manufacturing and Investment Zone and } \\
\text { development of first IIM in the state }\end{array}$ \\
\hline 4 & Jaipur & II & $\begin{array}{l}3 \text { million population, Tourist destination, young } \\
\text { population }\end{array}$ \\
\hline 5 & Lucknow & II & $\begin{array}{l}3 \text { million population, high education level, } \\
\text { household income is high }\end{array}$ \\
\hline 6 & Ludhiana & II & High consumption tendency \\
\hline 7 & Ahmedabad & II & $\begin{array}{l}\text { Largest city of Gujarat, population more than } 5 \\
\text { million }\end{array}$ \\
\hline 8 & Amritsar & II & Major tourist attraction, \\
\hline 9 & Indore & II & $\begin{array}{l}2.2 \text { million population, one of the largest city, large } \\
\text { middle income group population }\end{array}$ \\
\hline 10 & Vadodara & II & 2 million population, high growth potential \\
\hline
\end{tabular}




\begin{tabular}{|c|c|c|l|}
\hline 11 & $\begin{array}{c}\text { Pimpri- } \\
\text { chinchwad }\end{array}$ & II & $\begin{array}{l}1.7 \text { million population, Closure to Pune, Thriving } \\
\text { industrial and automobile manufacturing belt }\end{array}$ \\
\hline 12 & Gurgaon & II & $\begin{array}{l}1.5 \text { million population, close to Delhi, call center } \\
\text { capital of India }\end{array}$ \\
\hline 13 & Rajkot & II & 1.8 million population, high growth potential \\
\hline
\end{tabular}

\subsection{Education:}

Parents in these cities are more aware about the importance of higher education. They want their children learn in the English medium schools and go to metro cities to continue their education thus hoping for the bright future. There is a trend of young educated people entering into the IT sector, which is considerable high paying job, thus there is increase in per capita income. This increase in income level helped the parents, who are still staying in the small cities, to afford the luxury products. Their visits to their NRI children increased the awareness about the luxury products.

P. T George in his article "Hiring woes in Tier 2 \& 3 cities" (2014) focused on the following characteristics for tier II and tier III cities. Rajendra Shah, in his report on "Employability challenges in tier II cities" (2014) also reiterated the same thing.

\section{Challenges for the marketers:}

- Lower average disposable income

- Varying consumption pattern

- Non-efficient supply chain

- Availability of manpower

- Technologically backward

- Customers are price sensitive

Sudipto Ghosh (2014) in his article states some of the benefits of smaller towns:

- Untapped market

- High willingness of purchase

- Growing consumer acceptance

- No clutter of brands;

- Can get a first mover advantage

- Availability of cheaper real estate 


\section{Primary Survey:}

A survey of 500 respondents in the range of 15 to 65 years was carried out; 250 each from tier II and tier III cities. The survey was conducted for three months in cities spread across India like Akola, Amaravati, Nagpur from Maharashtra state, Jaipur, Jodhpur from Rajasthan, and other cities like Patna, Mangalore, Nashik, Bhubaneshwar etc. As the survey was about the fashion brands, so respondents of higher income were chosen to understand the buying pattern.

\section{Findings:}

It is evident from the survey that the behavior of customer from both cities is different in most of the cases, but as population, education level, awareness, and exposure of tier III cities were increasing it is moving towards the tier II city characteristics.

\section{Shopping Frequency:}
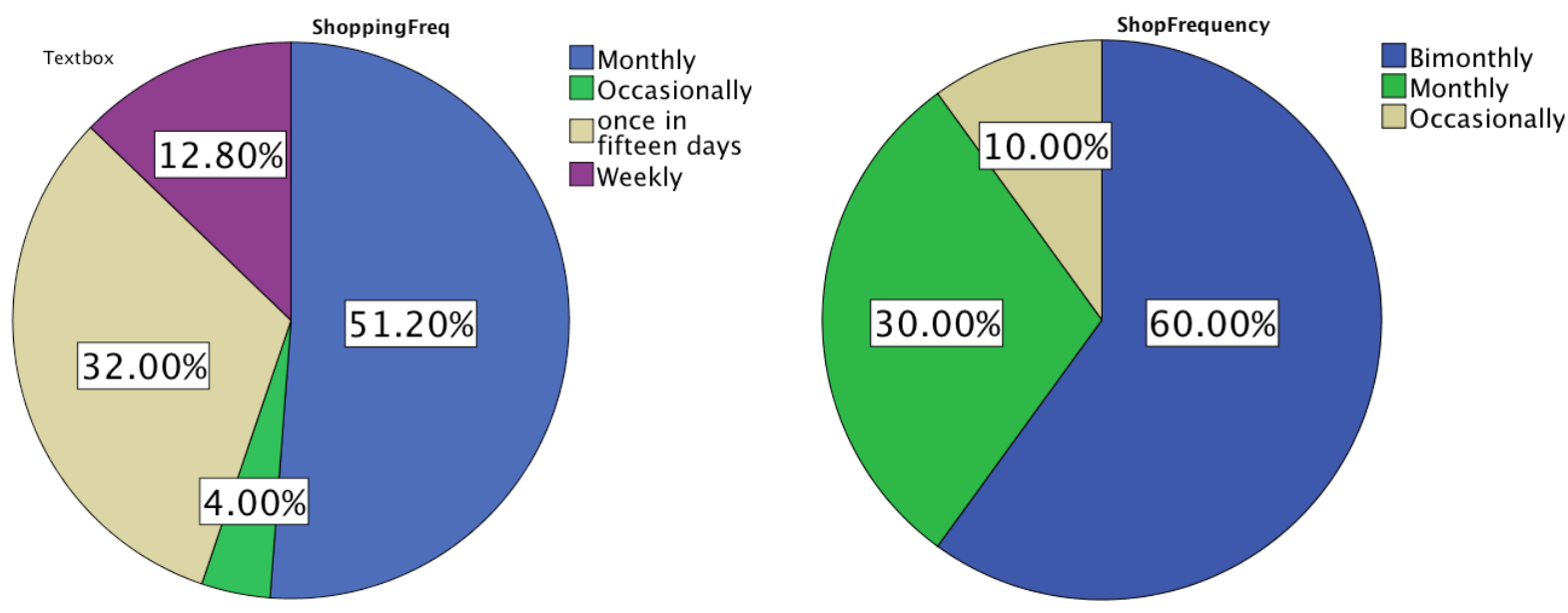

Tier

Tier III

II

Purchase frequency clearly indicates that in tier I almost $50 \%$ of respondents shop fashion products monthly, while the frequency reduces to a bimonthly in tier III. 


\section{Shopping preference:}

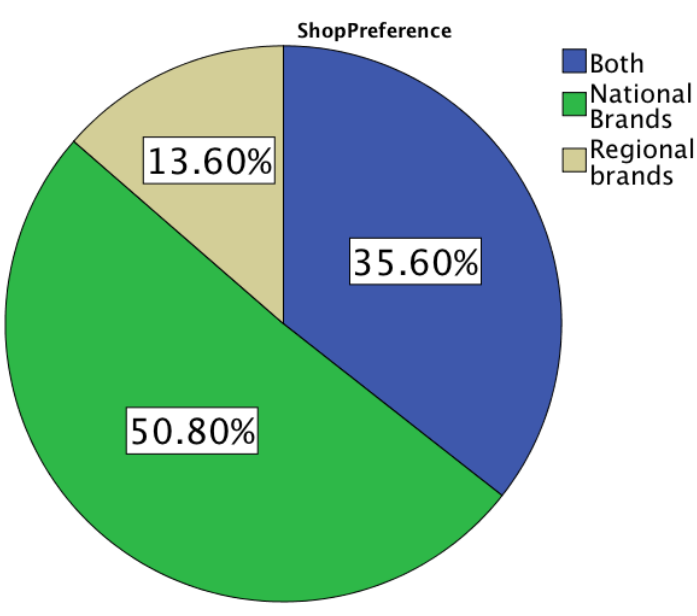

Tier II

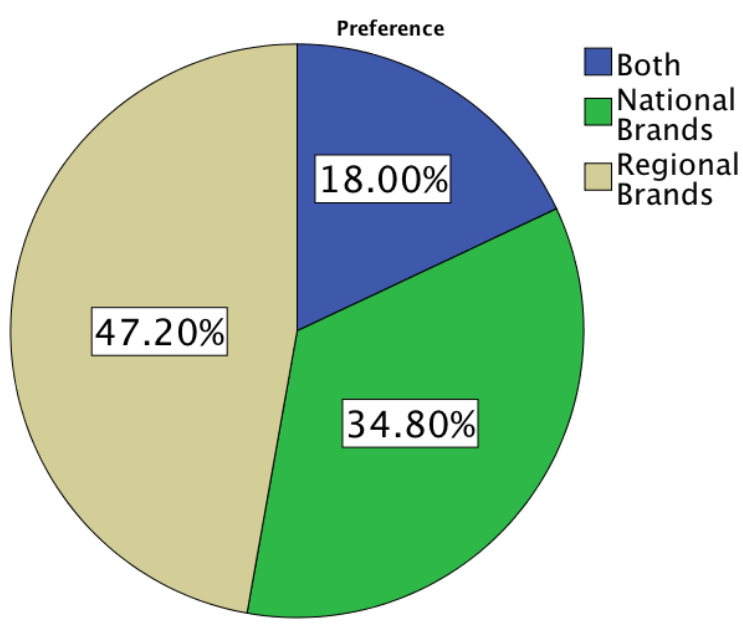

Tier III

As tier II cities have more exposure to the brands, it is obvious that they purchase more of the national brands, while the regional brands have more demand in the tier III cities.

\section{Shopping location:}

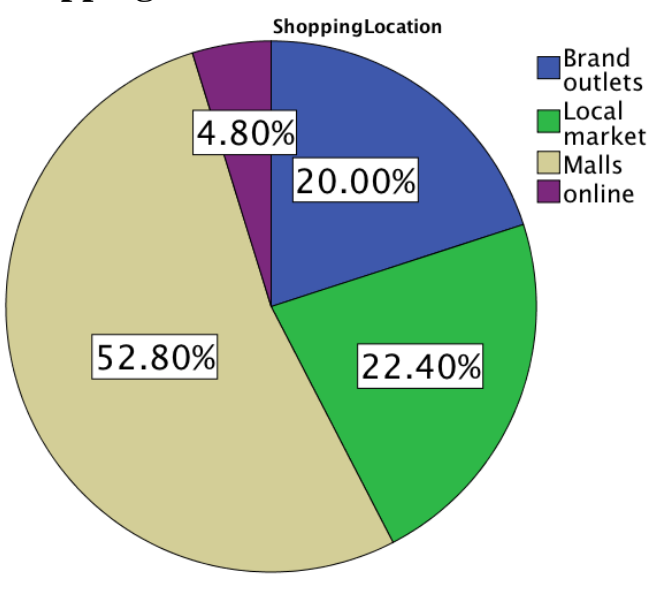

Tier II

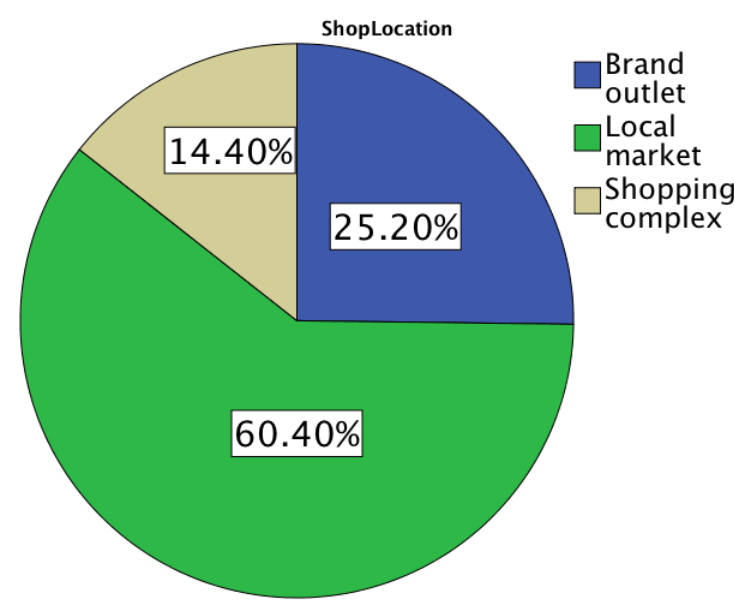

Tier III

For tier II, most respondents depend on the malls for the shopping and very few go to the brand stores and local market, as there are more options available in shopping complexes. But in tier III, absence of malls and brand outlets leads to dependence on the local market. One thing that is observed in such cities that people are well aware about the products, its varieties but such products 
are not accessible to them. People generally visit the metro cities near their place to purchase what they want. But such travel is not possible frequently. So such purchasing happens only when there is a business trip or during festivals.

\section{Source of awareness:}

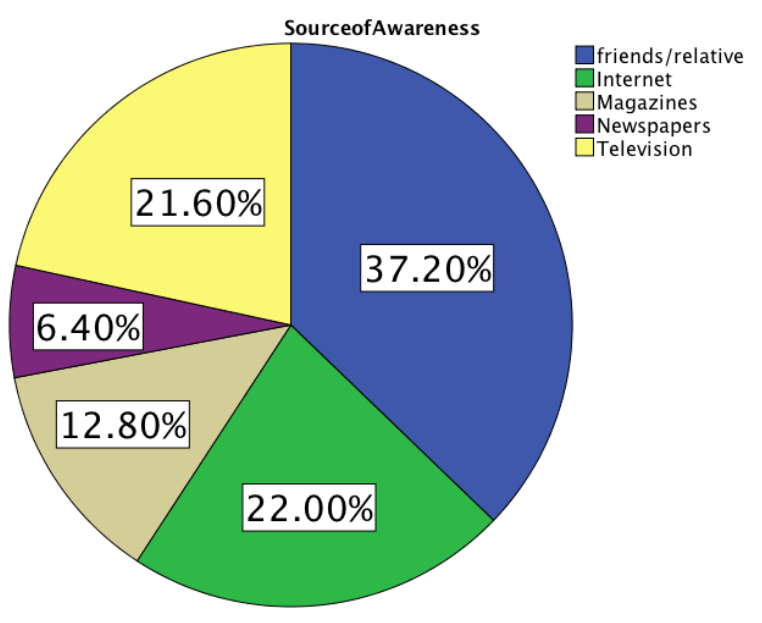

TIER II

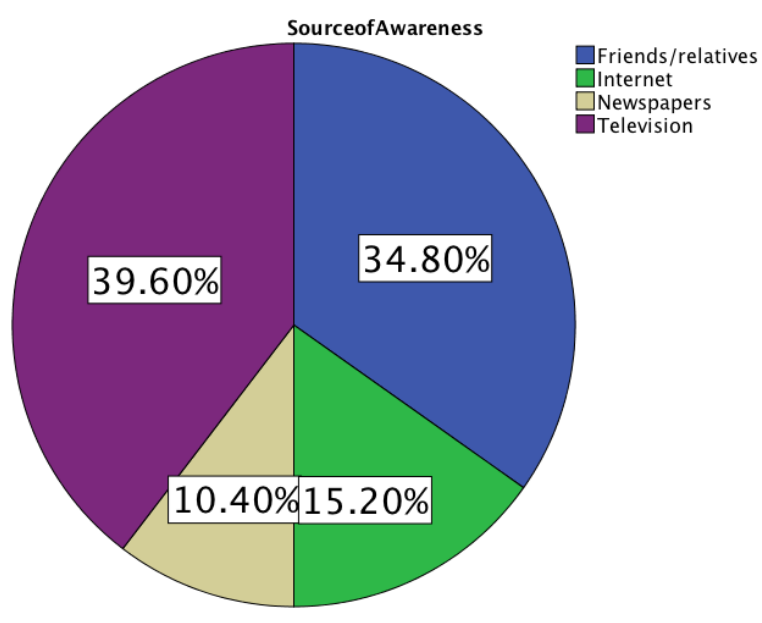

TIER III

It is interesting to know that respondents in both categories observe the purchases done by the friends and relatives and they like to have the similar product. In tier III TV is the main source for the awareness of fashion products. While in Tier II social sites plays important role. The younger generation spends most of the time on the social networking sites like Facebook, Whatsapp, Instagram etc. These are the avenues where they also get information about the latest trend in fashion. Brands cannot neglect such a huge potential customers. A right approach is needed to get the potential customer is come to the store. A social marketing concept on Whatsapp can be used for creating awareness about the availability of product. 


\section{Time of purchase:}

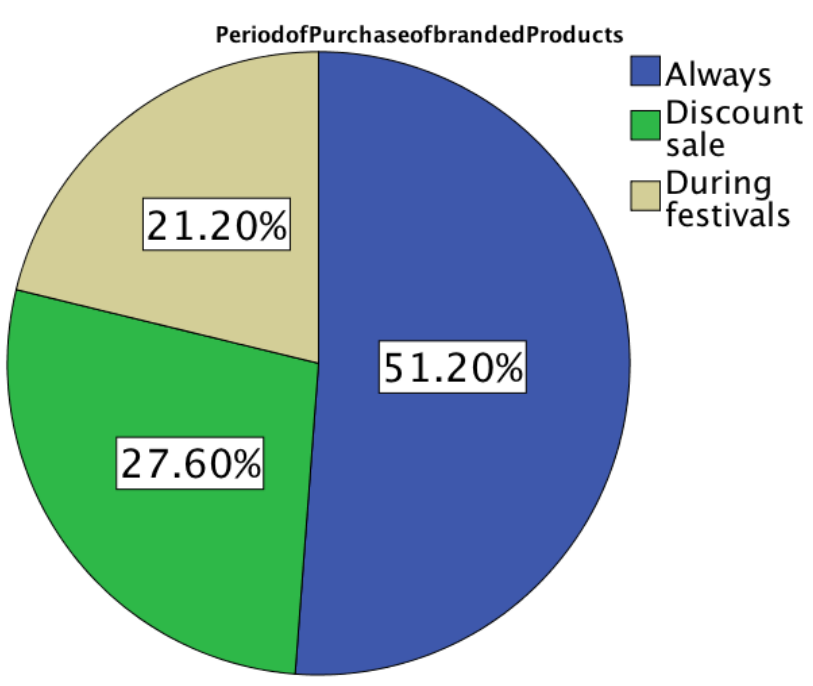

Tier II

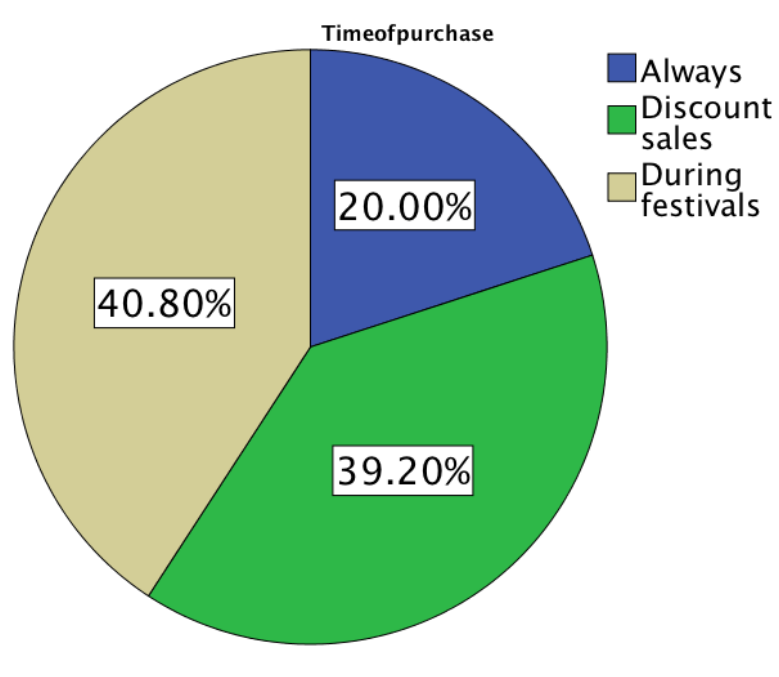

Tier III

Tier II customers are more loyal to brand and don't wait for the discount or festival seasons, while the purchase in tier III are mostly driven by festival and discount season. Celebration at festivals is the main highlight of the culture of these cities. Marketers need to tap such events to showcase such products. Direct selling at these events might be diluting the brands but promotions can be planned. 


\section{Reason for purchase:}

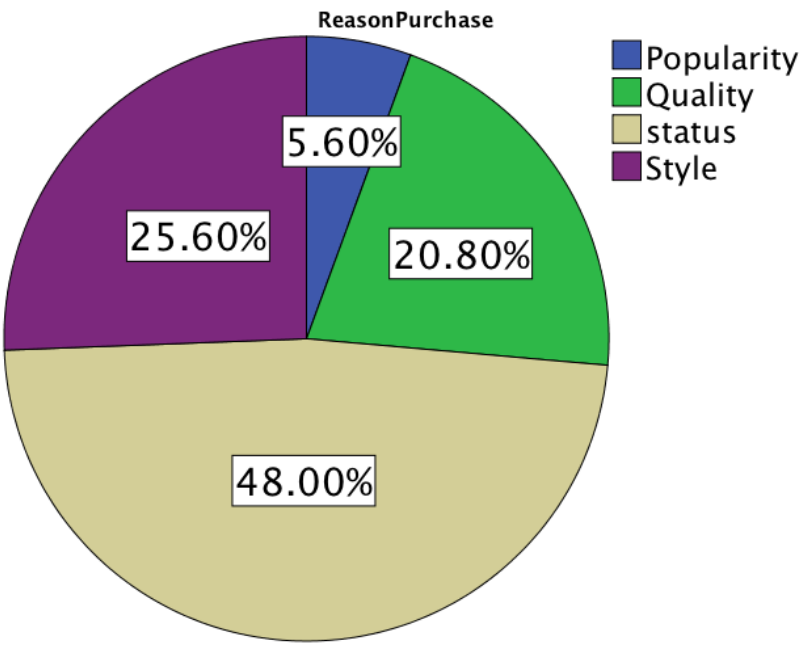

Tier II

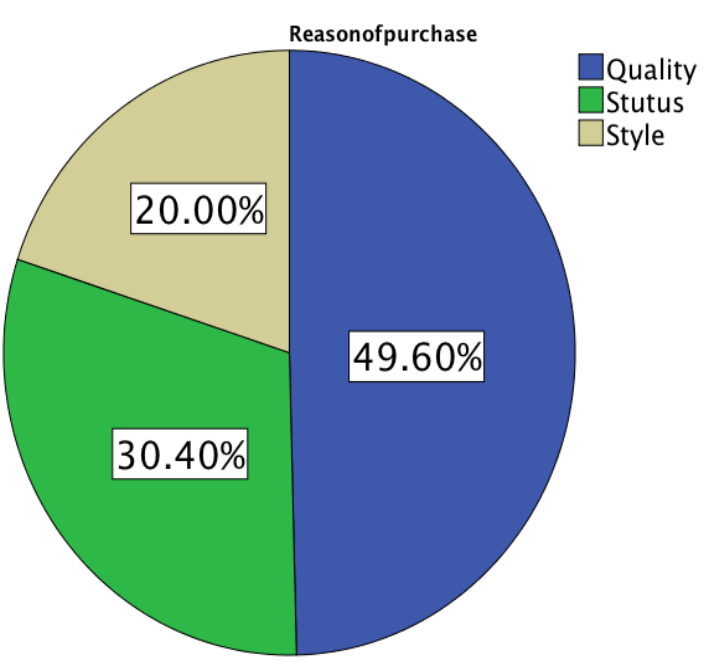

Tier III

Purchase of fashion products is considered as a status symbol in both tier II and III cities. But customers from tier II also checks for the quality aspect while advertisements influence customers from tier III.

\section{Analysis of survey:}

A survey clearly shows that the tier II and tier III cities have different characteristics in terms of shopping of fashion products. During the survey it was found out that factors like occupation, age, and income level majorly controls customer behavior. (As the survey includes both male and female respondents, gender factor is not considered separately here, but its impact is considered in other factors.) Depending on these factors a matrix for each was prepared to finalize the business model for the fashion business. While preparing these matrices, 4 P's of marketing were considered, which give insights into the consumer behavior of tier II and tier III customers. 
Tier II - Matrix with respect to Occupation:

\begin{tabular}{|c|c|c|c|c|}
\hline & Product & Price & Place & Promotion \\
\hline $\begin{array}{l}\text { Private } \\
\text { jobs }\end{array}$ & $\begin{array}{l}\text { Interested in } \\
\text { fashion products and } \\
\text { are more interested } \\
\text { in buying as well as } \\
\text { using them due to the } \\
\text { western work culture } \\
\text { adopted by private } \\
\text { organizations. More } \\
\text { accessibility and } \\
\text { knowledgeable; } \\
\text { prefers private labels }\end{array}$ & $\begin{array}{l}\text { More focused } \\
\text { on what value or } \\
\text { style the product } \\
\text { has. They are } \\
\text { more focused } \\
\text { towards status } \\
\text { than to think } \\
\text { about money, } \\
\text { could easily be } \\
\text { targeted for } \\
\text { premium and } \\
\text { super premium } \\
\text { products. }\end{array}$ & $\begin{array}{l}\text { Visiting to a } \\
\text { mall is their first } \\
\text { preference, } \\
\text { everything under } \\
\text { one roof, from } \\
\text { entertainment to } \\
\text { food, from } \\
\text { groceries to shoes. } \\
\text { Thus if a fashion } \\
\text { brand targeting this } \\
\text { segment they can } \\
\text { successfully be } \\
\text { placed near or in } \\
\text { the mall. }\end{array}$ & $\begin{array}{l}\text { Radio could be } \\
\text { one of the great } \\
\text { ways to target this } \\
\text { segment as in tier } \\
\text { one cities people } \\
\text { usually spend most } \\
\text { of their time in } \\
\text { traffic. Also } \\
\text { promoting } \\
\text { complexes or } \\
\text { movie theaters } \\
\text { could also be one } \\
\text { of the best ways. }\end{array}$ \\
\hline $\begin{array}{c}\text { Govt. } \\
\text { Employee }\end{array}$ & $\begin{array}{l}\text { More formal and } \\
\text { less interested in } \\
\text { fashion and } \\
\text { technological } \\
\text { products. But still } \\
\text { with the social media } \\
\text { growth and internet } \\
\text { reach in every office, } \\
\text { made it easy to } \\
\text { attract these } \\
\text { consumers towards } \\
\text { fashion products. } \\
\text { Prefers private labels }\end{array}$ & $\begin{array}{l}\text { Very price } \\
\text { sensitive. } \\
\text { Companies } \\
\text { should } \\
\text { understand the } \\
\text { govt. policies } \\
\text { and then need to } \\
\text { appropriately } \\
\text { place the brand. }\end{array}$ & $\begin{array}{l}\text { Convenience is } \\
\text { the critical factor } \\
\text { for them. }\end{array}$ & $\begin{array}{l}\text { Promoting the } \\
\text { product through } \\
\text { advertisements on } \\
\text { TV could target } \\
\text { this segment. }\end{array}$ \\
\hline Students & $\begin{array}{l}\text { Growing } \\
\text { awareness power, } \\
\text { Students tend to } \\
\text { spend money on } \\
\text { clothing and beauty } \\
\text { products, and find } \\
\text { these items to be } \\
\text { important, more } \\
\text { knowledgable about } \\
\text { the brands. }\end{array}$ & $\begin{array}{l}\text { They are } \\
\text { more attracted } \\
\text { towards brand } \\
\text { but they don't } \\
\text { earn so pricing a } \\
\text { product targeted } \\
\text { to them is a } \\
\text { difficult task. }\end{array}$ & $\begin{array}{l}\text { Targeting them } \\
\text { near colleges or in } \\
\text { colleges at the time } \\
\text { of fest are the most } \\
\text { beneficial way to } \\
\text { place a brand }\end{array}$ & $\begin{array}{l}\text { Digital } \\
\text { marketing the best } \\
\text { medium to target } \\
\text { this segment. Also } \\
\text { offers and } \\
\text { discounts }\end{array}$ \\
\hline $\begin{array}{l}\text { House } \\
\text { wives }\end{array}$ & 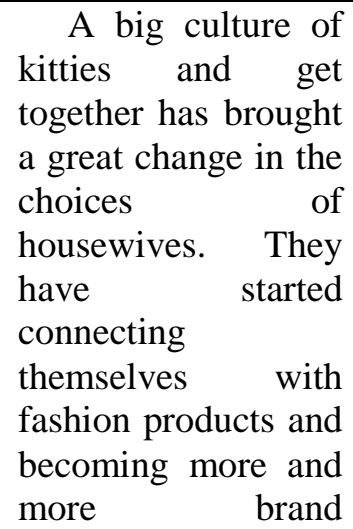 & $\begin{array}{l}\text { Though they } \\
\text { have become } \\
\text { brand conscious } \\
\text { they still got } \\
\text { bargaining } \\
\text { power in them } \\
\text { they choose a } \\
\text { product which } \\
\text { gives the best of } \\
\text { price and } \\
\text { quality. }\end{array}$ & $\begin{array}{l}\text { A place near } \\
\text { residential area } \\
\text { offering a great } \\
\text { environment to } \\
\text { freely roam around } \\
\text { and check and feel } \\
\text { the product could } \\
\text { be the ideal place } \\
\text { for them. Mall so } \\
\text { far has been the } \\
\text { hub for them to } \\
\text { shop. }\end{array}$ & $\begin{array}{l}\text { Promoting a } \\
\text { great deal like } \\
\text { combo package or } \\
\text { a discount offer }\end{array}$ \\
\hline
\end{tabular}




\begin{tabular}{|l|l|l|l|}
\hline & $\begin{array}{l}\text { conscious. They } \\
\text { want a product, } \\
\text { which compliments } \\
\text { their status in } \\
\text { society. }\end{array}$ & & \\
\hline
\end{tabular}

Tier II - Matrix with respect to Age ( $n$ years):

\begin{tabular}{|c|c|c|c|c|}
\hline & Product & Price & Place & Promotion \\
\hline $60+$ & $\begin{array}{l}\text { This segment needs } \\
\text { more of a comfort product } \\
\text { than the stylish one. They } \\
\text { see the need first and than } \\
\text { the status. They are more } \\
\text { brands loyal as they } \\
\text { experienced product over } \\
\text { the period. }\end{array}$ & $\begin{array}{l}\text { In tier II cities } \\
\text { people of this } \\
\text { segment look for } \\
\text { a value for money } \\
\text { than to a cheap } \\
\text { one }\end{array}$ & \begin{tabular}{l}
\multicolumn{2}{c}{ Home deliveries } \\
and personal \\
selling is more \\
preferred in this \\
segment.
\end{tabular} & $\begin{array}{l}\text { Showing } \\
\text { need of the } \\
\text { product for this } \\
\text { age through ads } \\
\text { would be } \\
\text { preferable. } \\
\text { Promotional } \\
\text { events, } \\
\text { association } \\
\text { with health } \\
\text { brand would be } \\
\text { beneficial }\end{array}$ \\
\hline $60^{35-}$ & $\begin{array}{l}\text { Choose their product } \\
\text { very carefully especially } \\
\text { fashion products like } \\
\text { apparels, accessories, etc. } \\
\text { They are more brands loyal } \\
\text { and do not easily switch the } \\
\text { brand. Prefer comfort, } \\
\text { class and sophistication } \\
\text { Prefers private labels }\end{array}$ & $\begin{array}{l}\text { If they are } \\
\text { loyal to the brand } \\
\text { they are ready to } \\
\text { pay for the } \\
\text { product offered. }\end{array}$ & $\begin{array}{l}\text { Brands } \\
\text { conscious so they } \\
\text { prefer to go to } \\
\text { EBOs where they } \\
\text { know what they } \\
\text { want to buy } \\
\text { without wasting } \\
\text { any time for } \\
\text { searching and } \\
\text { among others. }\end{array}$ & $\begin{array}{l}\text { Showing the } \\
\text { brand value is } \\
\text { the most } \\
\text { important way } \\
\text { to attract this } \\
\text { segment the } \\
\text { main aim } \\
\text { would be to } \\
\text { earn their trust } \\
\text { and loyalty. }\end{array}$ \\
\hline $35^{20-}$ & $\begin{array}{l}\text { Want to experiment with } \\
\text { their look and choices. } \\
\text { Always prefer new, trendy } \\
\text { and exclusive product. }\end{array}$ & \begin{tabular}{l}
\multicolumn{1}{c}{ This group } \\
needs to be \\
targeted $\quad$ by \\
offering great \\
deal. Offering \\
good price for a \\
differentiated \\
product
\end{tabular} & $\begin{array}{l}\text { Social media } \\
\text { influence is high on } \\
\text { this segment so e- } \\
\text { retailing, malls } \\
\text { could play a great } \\
\text { role to attract this } \\
\text { segment. }\end{array}$ & \begin{tabular}{l}
\multicolumn{1}{c}{ Digital } \\
marketing \\
through their \\
websites and \\
social media \\
will be the Key.
\end{tabular} \\
\hline $\begin{array}{l}\text { Belo } \\
\text { w } 20\end{array}$ & $\begin{array}{l}\text { They always get } \\
\text { attracted with product look } \\
\text { rather than the } \\
\text { functionality. }\end{array}$ & $\begin{array}{l}\text { Prefer low } \\
\text { priced product }\end{array}$ & $\begin{array}{l}\text { Malls could be } \\
\text { the great place to } \\
\text { target this segment }\end{array}$ & $\begin{array}{l}\text { Promoting } \\
\text { the brand } \\
\text { through the } \\
\text { personality, } \\
\text { digital } \\
\text { marketing }\end{array}$ \\
\hline
\end{tabular}


Tier II - Matrix with respect to Income (in INR):

\begin{tabular}{|c|c|c|c|c|}
\hline & Product & Price & Place & Promotion \\
\hline $\begin{array}{l}600,000 /- \\
\text { and above }\end{array}$ & $\begin{array}{l}\text { More attracted } \\
\text { towards luxury and } \\
\text { status products. } \\
\text { Willing to } \\
\text { experiment as they } \\
\text { means for the same. } \\
\text { Prefers national } \\
\text { labels }\end{array}$ & $\begin{array}{l}\text { They } \\
\text { concentrate } \\
\text { more on status } \\
\text { symbol than on } \\
\text { price. }\end{array}$ & $\begin{array}{l}\text { They love } \\
\text { good market } \\
\text { place where } \\
\text { there are more } \\
\text { brands to } \\
\text { choose from. }\end{array}$ & $\begin{array}{l}\text { Promotion through } \\
\text { luxury magazines, or } \\
\text { personalized mail will } \\
\text { help to connect them } \\
\text { better with brands. }\end{array}$ \\
\hline $\begin{array}{l}400,000- \\
600,000\end{array}$ & $\begin{array}{l}\text { This segment of } \\
\text { the society aspires } \\
\text { to gain the premium } \\
\text { and luxury product. } \\
\text { Prefers private } \\
\text { labels }\end{array}$ & $\begin{array}{l}\text { This segment } \\
\text { of society wants } \\
\text { quality as well } \\
\text { as a worthy } \\
\text { product, which } \\
\text { justify their } \\
\text { spending. }\end{array}$ & $\begin{array}{l}\text { E retailing } \\
\text { could be a } \\
\text { great platform } \\
\text { to target this } \\
\text { segment. }\end{array}$ & $\begin{array}{l}\text { Promoting different } \\
\text { financing schemes will } \\
\text { be profitable for this } \\
\text { segment. }\end{array}$ \\
\hline $\begin{array}{l}200,0000- \\
400,000\end{array}$ & $\begin{array}{l}\text { They look at the } \\
\text { functionality of the } \\
\text { product rather then } \\
\text { status value of the } \\
\text { product. Prefers } \\
\text { private labels }\end{array}$ & $\begin{array}{l}\text { They always } \\
\text { look for a low } \\
\text { price quality } \\
\text { product. }\end{array}$ & $\begin{array}{l}\text { This } \\
\text { segment wants } \\
\text { to see, touch } \\
\text { and feel before } \\
\text { buying any } \\
\text { fashion } \\
\text { product. }\end{array}$ & $\begin{array}{l}\text { Sales discounts and } \\
\text { other offers could be } \\
\text { used to target this } \\
\text { segment. }\end{array}$ \\
\hline $\begin{array}{r}\text { Below } \\
200,000 /-\end{array}$ & 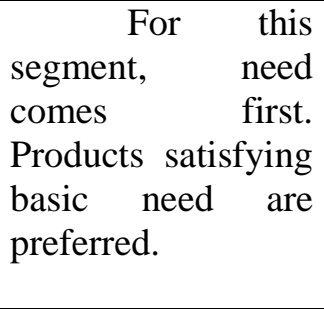 & 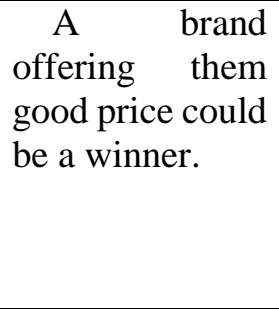 & $\begin{array}{l}\text { Nearby } \\
\text { retail store } \\
\text { could be the } \\
\text { best place to } \\
\text { target this } \\
\text { segment. }\end{array}$ & $\begin{array}{l}\text { Through television } \\
\text { and radio ads, as they } \\
\text { are large in number and } \\
\text { in Tier II cities, people } \\
\text { still depend on TV and } \\
\text { radio for product } \\
\text { awareness. }\end{array}$ \\
\hline
\end{tabular}


Tier III - Matrix with respect to Occupation:

\begin{tabular}{|c|c|c|c|c|}
\hline & Product & Price & Place & Promotion \\
\hline $\begin{array}{l}\text { Private } \\
\text { jobs }\end{array}$ & $\begin{array}{l}\text { Have limited } \\
\text { exposure and well } \\
\text { aware about the } \\
\text { products. They are } \\
\text { ready travel for } \\
\text { purchase to another } \\
\text { city, more focused } \\
\text { on their social image } \\
\text { Prefers private } \\
\text { labels }\end{array}$ & \begin{tabular}{l}
\multicolumn{2}{c}{ Like to } \\
experience with \\
high priced \\
products.
\end{tabular} & $\begin{array}{l}\quad \text { Mostly they } \\
\text { want to } \\
\text { experience the } \\
\text { same in the } \\
\text { nearby } \\
\text { shopping mall. }\end{array}$ & $\begin{array}{c}\text { Television and } \\
\text { theater advertisement }\end{array}$ \\
\hline $\begin{array}{c}\text { Govt. } \\
\text { Employee }\end{array}$ & $\begin{array}{l}\text { The customers in } \\
\text { this category are less } \\
\text { experimental, } \\
\text { mostly fashion } \\
\text { laggards. Prefers } \\
\text { local brands }\end{array}$ & $\begin{array}{l}\text { Sensitive to } \\
\text { prices. }\end{array}$ & $\begin{array}{l}\text { Convenience } \\
\text { is the critical } \\
\text { factor for them. }\end{array}$ & $\begin{array}{l}\quad \text { Targeted by } \\
\text { promoting the product } \\
\text { through } \\
\text { advertisements on } \\
\text { TV. }\end{array}$ \\
\hline Students & $\begin{array}{l}\text { Influenced by the } \\
\text { celebrity's fashions. } \\
\text { But generate high } \\
\text { demand and always } \\
\text { wants to experiment. }\end{array}$ & $\begin{array}{l}\text { Lesser the } \\
\text { better }\end{array}$ & $\begin{array}{l}\text { Targeting } \\
\text { them near } \\
\text { colleges or in } \\
\text { colleges at the } \\
\text { time of fest or e- } \\
\text { retailing }\end{array}$ & $\begin{array}{l}\text { Digital marketing } \\
\text { through their websites } \\
\text { and social Also offers } \\
\text { and discounts }\end{array}$ \\
\hline $\begin{array}{l}\text { House } \\
\text { wives }\end{array}$ & $\begin{array}{l}\text { They want more } \\
\text { functionality in the } \\
\text { product and not so } \\
\text { aware about the } \\
\text { fashion products. }\end{array}$ & $\begin{array}{l}\text { Highly price } \\
\text { sensitive } \\
\text { specifically } \\
\text { towards high } \\
\text { priced products. } \\
\text { A hard } \\
\text { bargainer. }\end{array}$ & $\begin{array}{l}\text { The main } \\
\text { market of the } \\
\text { city }\end{array}$ & \begin{tabular}{lr}
\multicolumn{2}{c}{ A discount offer, A } \\
promotional & event \\
near a a main \\
residential area
\end{tabular} \\
\hline
\end{tabular}


Tier III - Matrix with respect to Age:

\begin{tabular}{|c|c|c|c|c|}
\hline & Product & Price & Place & Promotion \\
\hline $60+$ & $\begin{array}{l}\text { Basically averse } \\
\text { to the fashion } \\
\text { products. }\end{array}$ & $\begin{array}{cc}\text { A } & \text { hard } \\
\text { bargainer. } & \end{array}$ & $\begin{array}{l}\text { local market } \\
\text { place is good } \\
\text { place to trade. }\end{array}$ & $\begin{array}{c}\text { Newspaper } \\
\text { advertisements }\end{array}$ \\
\hline $35-60$ & $\begin{array}{l}\text { Experiment with } \\
\text { the fashion products. } \\
\text { High growth } \\
\text { potential. Mostly } \\
\text { formals garments, } \\
\text { footwear are the } \\
\text { products they are } \\
\text { looking for. Prefers } \\
\text { private labels }\end{array}$ & $\begin{array}{l}\text { Quality is } \\
\text { preferred than } \\
\text { price. They love to } \\
\text { buy product, } \\
\text { which justify their } \\
\text { spending. }\end{array}$ & $\begin{array}{l}\text { A shopping } \\
\text { complex where } \\
\text { there are more } \\
\text { products to look } \\
\text { and try out for. }\end{array}$ & $\begin{array}{l}\text { Use Social sites; } \\
\text { newspapers, and TV } \\
\text { are the right } \\
\text { promotional } \\
\text { strategy. }\end{array}$ \\
\hline $20-35$ & \begin{tabular}{lr}
\multicolumn{1}{c}{ Want } & to \\
experiment & with \\
their look and \\
choices. \\
energetic and hence \\
willing to relate their \\
personality with \\
brand. Always \\
prefer new, trendy \\
and exclusive \\
product.
\end{tabular} & \begin{tabular}{l}
\multicolumn{2}{c}{ Offering good } \\
price for a \\
differentiated \\
product is the \\
strategy to be \\
adopted for this \\
segment
\end{tabular} & $\begin{array}{l}\text { Social media } \\
\text { influence is high } \\
\text { on this segment } \\
\text { so e- retailing } \\
\text { could be the best } \\
\text { place to target } \\
\text { them. }\end{array}$ & $\begin{array}{l}\text { Digital marketing } \\
\text { through their } \\
\text { websites and social } \\
\text { media Also offers } \\
\text { and discounts }\end{array}$ \\
\hline $20^{\text {Below }}$ & $\begin{array}{l}\text { They always get } \\
\text { attracted with } \\
\text { product look rather } \\
\text { than } \\
\text { functionality. }\end{array}$ & $\begin{array}{l}\text { Always try for } \\
\text { the lesser price }\end{array}$ & $\begin{array}{l}\text { E-commerce, } \\
\text { shopping } \\
\text { complex }\end{array}$ & $\begin{array}{l}\text { Also social media } \\
\text { celebrity } \\
\text { endorsements }\end{array}$ \\
\hline
\end{tabular}


Tier III - Matrix with respect to Income (In INR):

\begin{tabular}{|c|c|c|c|c|}
\hline & Product & Price & Place & Promotion \\
\hline $600,000 /-$ & $\begin{array}{l}\text { Difficult to pitch to } \\
\text { More concerned about } \\
\text { the saving than } \\
\text { purchasing Prefers } \\
\text { private labels, prefers }\end{array}$ & $\begin{array}{l}\text { Ready to pay } \\
\text { more for a } \\
\text { quality and a } \\
\text { branded product. }\end{array}$ & $\begin{array}{l}\text { Market } \\
\text { place where } \\
\text { there are more } \\
\text { brands to } \\
\text { choose from. }\end{array}$ & $\begin{array}{l}\text { Have } \\
\text { very limited } \\
\text { sources } \\
\text { information, } \\
\text { mostly depend on } \\
\text { newspaper and TV }\end{array}$ \\
\hline $\begin{array}{l}400,000- \\
600,000\end{array}$ & $\begin{array}{l}\text { Aspires to gain the } \\
\text { premium and luxury } \\
\text { product, This segment } \\
\text { also has good } \\
\text { knowledge about } \\
\text { brands, Prefers private } \\
\text { labels }\end{array}$ & $\begin{array}{l}\text { This segment } \\
\text { of society wants } \\
\text { quality as well as } \\
\text { a worthy } \\
\text { product, which } \\
\text { justify their } \\
\text { spending. }\end{array}$ & E-retailing & $\begin{array}{l}\text { Promoting } \\
\text { different financing } \\
\text { schemes will be } \\
\text { profitable for this } \\
\text { segment. }\end{array}$ \\
\hline $\begin{array}{l}200,0000- \\
400,000\end{array}$ & $\begin{array}{l}\text { Functionality of the } \\
\text { product rather then } \\
\text { status value of the } \\
\text { product. }\end{array}$ & $\begin{array}{l}\text { Always look } \\
\text { for a low price } \\
\text { quality product. } \\
\text { Ready to travel } \\
\text { to nearby }\end{array}$ & $\begin{array}{l}\text { Want to see, } \\
\text { touch and feel } \\
\text { before buying } \\
\text { any fashion } \\
\text { product }\end{array}$ & $\begin{array}{l}\text { Sales discounts } \\
\text { and other offers }\end{array}$ \\
\hline $\begin{array}{r}\text { Below } \\
200,000 /-\end{array}$ & $\begin{array}{l}\text { Buy low quality } \\
\text { brand copies. }\end{array}$ & $\begin{array}{l}\text { Price is the } \\
\text { most important } \\
\text { criteria for them. }\end{array}$ & $\begin{array}{lr} & \text { Easy } \\
\text { availability, so } \\
\text { nearby retail } \\
\text { store }\end{array}$ & $\begin{array}{l}\text { Could best be } \\
\text { targeted through } \\
\text { television as they } \\
\text { are large in number }\end{array}$ \\
\hline
\end{tabular}

\section{Conclusion}

It is no doubt that tier II and tier III cities provide immense opportunities for the companies for expansion. But the right business model and marketing mix is important for the success for these brands. The brands can take the private labels forward, which can provide the perfect option for the small town customer. It is also obvious that the currently there demand for the fashion and lifestyle brands in tier III cities is slightly sluggish, but the days are not far when the brands realize that there is enough clutter in the metro cities and the companies will rush to these untapped market with huge potential.

It is important to find out the demographics of the particular region and offer a right product at right price. Thus the marketer needs to map the areas to be targeted, after understanding the product offerings, changing the product characteristics if required. It catered properly these cities will give immense return on investment to the companies. 


\section{References:}

- http://tech.economictimes.indiatimes.com/news/internet/amazon-fashion-witnessesmore-than-50-of-its-demand-from-tier-2-cities/48305931,Shilpa Elizabeth, ET Bureau Jul 31, 2015

- Emerging Consumer Demand: Rise of the Small Town Indian’ Nielsen and CII report 2012

- http://articles.economictimes.indiatimes.com/2011-12-04/news/30472124_1_retailreal-estate-big-retail-chains-tier-iii

- http://www.nasscom.in/looking-beyond-tierlandscape?fg=127463\#sthash.fL9iOUXb.dpuf

- http://www.yourarticlelibrary.com/india-2/retail-destinations-in-india-withdiagram-and-statistics/48448/

- http://browntape.com/tier-2-3-cities-as-potential-markets-for-online-retail/

- Retail Realty in India:

- A Comparison and Contrast with the Emerging Cities of Asia, Retail Intelligence I February 2014 Evolution and Potential

- http://articles.economictimes.indiatimes.com/2015-08-18/news/65530671_1_tier-iicities-smaller-cities-4-cities

- titled the 'Indian IT-BPO Industry: Driving India's Socio Economic Transformation,' NASSCOM 2010

- http://www.peoplematters.in/article/2014/05/01/talent-acquisition/hiring-woes-intier-2-and-3-cities/5020

- http://www.ssoindia.com/AgendaSection.aspx?tp_day=131370\&tp_session=52949

- https://www.quora.com/What-are-some-of-the-advantages-of-living-in-smallIndian-cities-towns-Tier-II-cities-over-the-Tier-I-cities-or-the-metros

- http://www.unmetro.in/nonmetro-awakening/unmetro-india-accounts-for-over-50of-trade-on-ebay-india/

- http://www.newsnation.in/article/33700-e-commerce-india-touch-usd-60-billion2023.html

- https://stakebusinesssolutions.wordpress.com/2015/02/15/how-to-create-a-strongbrand-positioning-part-3/ 
8th International Conference on Modern Research in

Management, Economics and Accounting

October 19 - 21, 2018 / Munich - Germany

- $\quad$ https://www.ibef.org/industry/retail-india.aspx

- http://www.zeebiz.com/small-business/news-fashion-apparel-are-men-shoppingmore-than-women-online-16578

- https://economictimes.indiatimes.com/tech/internet/internet-users-in-indiaexpected-to-reach-500-million-by-june-iamai/articleshow/63000198.cms

- https://www.trai.gov.in/sites/default/files/PR_No.56_Eng.pdf

- https://www.thehindubusinessline.com/companies/india-to-have-175-m-onlineshoppers-by-2020/article8673698.ece 